\title{
Management of Dry Root Rot of Chickpea Caused by Rhizoctonia bataticola through Fungicides
}

\author{
S. Ravichandran* and Yashoda R. Hegde \\ Department of Plant Pathology College of Agriculture, University of Agricultural Sciences, \\ Dharwad- 580 005, India \\ *Corresponding author
}

\begin{tabular}{|c|c|}
\hline & A B S T R A C T \\
\hline $\begin{array}{l}\text { K e y w or d s } \\
\text { Chickpea, } \\
\text { Cicer arietinum } \\
\text { L., Fungicides, } \\
\text { Dry root rot, } \\
\text { Rhizoctonia } \\
\text { bataticola. }\end{array}$ & \multirow{3}{*}{$\begin{array}{l}\text { A lab experiment was conducted to evaluate six combiproduct, five contact } \\
\text { and four systemic fungicides against Rhizoctonia bataticola causing dry } \\
\text { root rot in chickpea. Among combiproducts evaluated, carbendazim } 25 \%+ \\
\text { mancozeb } 50 \% \text { (Sprint), carboxin } 37.5 \%+\text { thiram } 37.5 \% \text { (Vitavax power } \\
75 \% \text { WP) and carbendazim } 12 \%+\text { mancozeb } 63 \% \text { (Saaf) were found to be } \\
\text { most effective with complete inhibition of mycelial growth of } R \text {. bataticola } \\
\text { at all the concentrations tested. Among the contact fungicides tested, } \\
\text { chlorothalonil and mancozeb at } 0.2 \% \text { were effective in inhibiting cent per } \\
\text { cent inhibition. Among the four systemic fungicides evaluated against } R \text {. } \\
\text { bataticola, carbendazim, difenconazole and tebuconazole were best with } \\
\text { cent per cent inhibition of mycelial growth at all concentrations tested. }\end{array}$} \\
\hline Article Info & \\
\hline $\begin{array}{l}\text { Accepted: } \\
\text { 19 June } 2017 \\
\text { Available Online: } \\
\text { 10 July } 2017\end{array}$ & \\
\hline
\end{tabular}

\section{Introduction}

Chickpea (Cicer arietinum L.) is one of the major grain legumes grown worldwide. It is a rich source of protein (20 to $25 \%$ ) and also enriches soil fertility by biological nitrogen fixation (Zia-Ul-Haq et al., 2007). It is of prime importance in the Mediterranean basin and South Asia. The crop is vulnerable to a number of air-borne and soil-borne diseases, some of which are devastating. Chickpea suffers from 172 pathogens consisting of fungi, bacteria, viruses and nematodes. The soil borne diseases, which severely damage the chickpea under favourable conditions are dry root rot caused by Rhizoctonia bataticola, Wilt caused by Fusarium oxysporum ciceri and collar rot caused by Sclerotium rolfsii (Ravichandran et al., 2014) and in coleus (Hegde et al., 2014). In the present study fungicides were evaluated under laboratory condition, to know their efficacy against $R$. bataticola causing dry root rot.

\section{Materials and Methods}

Experiment was conducted in order to find out the suitable fungicide in inhibiting $R$. bataticola by poison food technique (Nene and Thapliyal, 1973). The details of the fungicides are presented below. 
Combi products were used at $0.05,0.1$ and 0.2 per cent

\begin{tabular}{|c|c|c|c|}
\hline $\begin{array}{l}\text { Sl. } \\
\text { No. }\end{array}$ & Common name & Chemical name & Trade name \\
\hline 1 & $\begin{array}{l}\text { Carbendazim } 12 \% \\
+ \text { Mancozeb } 63 \% \\
\text { WP }\end{array}$ & $\begin{array}{l}\text { Methyl benzimidazole carbonate }+ \\
\text { Manganese zinc ethylene bis } \\
\text { dithiocarbomate }+ \text { zinc }\end{array}$ & Saaf $75 \%$ WP \\
\hline 2 & $\begin{array}{l}\text { Zineb } 68 \%+ \\
\text { Hexaconazole } \\
\text { 4\%WP }\end{array}$ & $\begin{array}{l}\text { (RS) -2- (2,4-dicholoro phenyl) -1- } \\
(1 \mathrm{H}-1,2,4 \text {-triazole-1-yl) -hexan-2-01 } \\
\left(\mathrm{C}_{14} \mathrm{H}_{17} \mathrm{Cl}_{2} \mathrm{~N}_{3} \mathrm{O}\right)+\text { zinc ethylene-1,2- } \\
\text { bisdithiocarbamate }\end{array}$ & Avtar $72 \% \mathrm{WP}$ \\
\hline 3 & $\begin{array}{l}\text { Carboxin } 37.5 \%+ \\
\text { Thiram } 37.5 \%\end{array}$ & 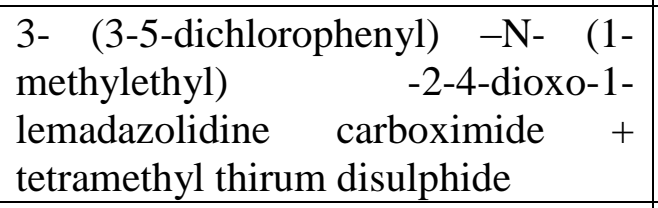 & Vitavax power $75 \% \mathrm{WP}$ \\
\hline 4 & $\begin{array}{l}\text { Carbendazim } 25 \% \\
+ \text { Mancozeb } 50 \% \\
\text { WP }\end{array}$ & $\begin{array}{l}\text { Methyl } 2 \text { Benzimidazole carbomate } \\
25+\text { Manganese ethylene bis } \\
\text { dithiocarbonate }+ \text { zinc } 50\end{array}$ & Sprint $75 \% \mathrm{WP}$ \\
\hline 5 & $\begin{array}{lr}\text { Captan70\% } & + \\
\text { Hexaconazole } & 5 \% \\
\text { WP }\end{array}$ & $\begin{array}{l}\text { N-trichloromethyl mercapta 4- } \\
\text { cyclohexene-1,2-dis carboximide N- } \\
\text { trichloromethyl thiotetra hydro } \\
\text { othalamide + RS) }-2-(2,4-d i c h l o r o \\
\text { phenyl)-1- }(14-1,2,4 \text {-triazole-1 yl }) \\
\text { hexane-2-1 }\end{array}$ & Taqat $75 \% \mathrm{WP}$ \\
\hline 6 & $\begin{array}{ll}\text { Tricyclazole } & 18 \% \\
+ \text { Mancozeb } & 62 \% \\
\text { WP }\end{array}$ & $\begin{array}{l}\text {-methyl-1, 2, 4-triazole }(3,4 b) \\
\text { Benzothiazole } 18+\text { Manganese } \\
\text { ethylene bis dithiocarbonate plus } \\
\text { zinc } 62\end{array}$ & Merger $80 \mathrm{WP}$ \\
\hline
\end{tabular}

Systemic fungicides were used at $0.025,0.05$ and 0.1 per cent

\begin{tabular}{|l|l|l|l|}
\hline Sl. No. & Common name & Chemical name & Trade name \\
\hline 1 & Hexaconazole & $\begin{array}{l}\text { (RS) -2- (2,4-dichloro phenyl) -1- } \\
(14-1,2,4-t \text { triazole-1 yl) hexane-2-1 }\end{array}$ & Contaf 5\%EC \\
\hline 2 & Propiconazole & $\begin{array}{l}\text { 1- (2,4 di chlorophenyl) -4-ropyl- } \\
1,3-\text {-dioxolan-2-methyl } \text {-H-1,4- } \\
\text { triozole }\end{array}$ & Tilt 25EC \\
\hline 3 & Difenconazole & $\begin{array}{l}1-(2-(4-\text { (4-chlorophenoxy) -2- } \\
\text { chlorophenyl)-4-methyl-1,3-dioxol- } \\
\text { 2yimethyl-1)-14-1,2,4-triazole }\end{array}$ & Score 25\%EC \\
\hline 4 & Carbendazim & $\begin{array}{l}\text { 2- (methoxy-carbomyl) } \\
\text { benzimidazole }\end{array}$ & Bavistin 50\%WP \\
\hline
\end{tabular}


Contact fungicides were evaluated at $0.1,0.2$ and 0.3 per cent

\begin{tabular}{|l|l|l|l|}
\hline $\begin{array}{l}\text { Sl. } \\
\text { No. }\end{array}$ & $\begin{array}{l}\text { Common } \\
\text { name }\end{array}$ & Chemical name & Trade name \\
\hline 1 & Captan & $\begin{array}{l}\text { N-trichloromethyl mercapta 4- } \\
\text { cyclohexene-1,2-dis carboximide N- } \\
\text { trichloromethy thiotetra hydro } \\
\text { othalamide }\end{array}$ & \\
\hline 2 & Mancozeb & $\begin{array}{l}\text { Manganese zinc ethylene bis } \\
\text { dithiocarbomate + zinc }\end{array}$ & Indofil M 45 WP \\
\hline 3 & Chlorothalonil & Tetrachloroisophthalonitrate & Kavach 75\% WP \\
\hline 4 & COC & Copper oxy chloride & Blitox 50 WP \\
\hline
\end{tabular}

Required quantity of individual fungicide was added separately into sterilized molten and cooled potato dextrose agar so as to get the desired concentration of the fungicides. Later, $20 \mathrm{ml}$ of the poisoned medium was poured into sterilized Petri plate. Mycelial disc of five $\mathrm{mm}$ size from actively growing zone of seven days old culture was cut by a sterile cork borer and one such disc was placed at the centre of each agar plate. Control treatment was maintained without adding any fungicide to the medium. Three replications were maintained for each treatment. Then such plates were incubated at room temperature and radial growth was measured when fungus attained maximum growth in control plates. Per cent inhibition of mycelial growth over control was calculated. The per cent inhibition of the growth of the pathogen was calculated by using the formula given by Vincent (1947).

$$
\mathrm{I}=\quad \frac{\mathrm{C}-\mathrm{T}}{\mathrm{C}} \times 100
$$

$\mathrm{I}=$ Per cent inhibition

$\mathrm{C}=$ Radial growth in control

$\mathrm{T}=$ Radial growth in treatment

Results and Discussion

\section{In vitro evaluation of combiproduct fungicides}

Among the six combiproducts evaluated against $R$. bataticola, carbendazim $25 \%+$ mancozeb 50\% (Sprint), carboxin 37.5\% + thiram $37.5 \%$ (Vitavax power $75 \% \mathrm{WP}$ ) and carbendazim 12\% + mancozeb 63\% (Saaf) were found to be most effective and significantly superior to all other fungicides, which inhibited cent per cent growth of Rhizoctonia bataticola at all the concentrations tested. Least inhibition of mycelial growth $(60.68 \%)$ was observed in captan 70\% + Hexaconazole 5\% (Taquat $75 \% \mathrm{WP})$ and at 0.1 per cent concentration with the inhibition of $51.48 \%$ (Table 1). In Rhizoctonia bataicola carbendazim 25\% + mancozeb 50\% (Sprint), carboxin 37.5\% + thiram $37.5 \%$ (Vitavax power 75\% WP) and carbendazim $12 \%+$ mancozeb $63 \%$ (Saaf) were found to be most effective and significantly superior to all other fungicides, which inhibited cent per cent growth whereas the least inhibition of mycelial growth $(60.68 \%)$ was observed in captan70\% + Hexaconazole 5\% (Taquat 75\%WP) at 0.1per cent concentration with the inhibition of $51.48 \%$. Similar results were observed by Ammajamma and Hegde (2009) in coleus. The combiproduct fungicides avoid the development of resistance by pathogens to systemic fungicides because these systemic fungicides interfere with only one or sometimes two functions in fungal physiology which is easily overcome by either a single mutation or by selection of resistant individuals in a population. 
Table.1 In vitro evaluation of combi product fungicides against Rhizoctonia bataticola

\begin{tabular}{|c|c|c|c|c|c|}
\hline \multirow{3}{*}{ Fungicides } & \multirow{3}{*}{$\begin{array}{l}\text { Trade } \\
\text { name }\end{array}$} & \multirow{2}{*}{\multicolumn{3}{|c|}{$\begin{array}{c}\text { Inhibition of mycelial growth } \\
(\%)\end{array}$}} & \multirow{3}{*}{ Mean } \\
\hline & & & & & \\
\hline & & 0.1 & 0.2 & 0.3 & \\
\hline Zineb $68 \%$ + Hexaconazole 4\%WP & Avtar & $\begin{array}{c}79.44 \\
(63.13)\end{array}$ & $\begin{array}{c}88.52 \\
(70.64)\end{array}$ & $\begin{array}{l}100.00 \\
(90.05)\end{array}$ & $\begin{array}{c}\mathbf{8 9 . 3 2} \\
(74.61)\end{array}$ \\
\hline Tricyclazole 18\%WP + Mancozeb 62\%WP & Merger & $\begin{array}{c}92.59 \\
(74.31)\end{array}$ & $\begin{array}{c}100.00 \\
(90.05)\end{array}$ & $\begin{array}{l}100.00 \\
(90.05)\end{array}$ & $\begin{array}{c}\mathbf{9 7 . 5 3} \\
(84.80)\end{array}$ \\
\hline Carbendazim 12\% + Mancozeb $63 \%$ & Saaf & $\begin{array}{l}100.00 \\
(90.05)\end{array}$ & $\begin{array}{l}100.00 \\
(90.05)\end{array}$ & $\begin{array}{l}100.00 \\
(90.05)\end{array}$ & $\begin{array}{l}\mathbf{1 0 0 . 0 0} \\
(90.05)\end{array}$ \\
\hline Carbendazim 25\% + Mancozeb $50 \%$ WP & Sprint & $\begin{array}{l}100.00 \\
(90.05)\end{array}$ & $\begin{array}{l}100.00 \\
(90.05)\end{array}$ & $\begin{array}{l}100.00 \\
(90.05)\end{array}$ & $\begin{array}{l}\mathbf{1 0 0 . 0 0} \\
(90.05)\end{array}$ \\
\hline Captan70\%+Hexaconazole 5\% WP & Taquat & $\begin{array}{c}51.48 \\
(45.87)\end{array}$ & $\begin{array}{c}65.74 \\
(54.21)\end{array}$ & $\begin{array}{c}64.81 \\
(53.66)\end{array}$ & $\begin{array}{c}\mathbf{6 0 . 6 8} \\
(51.25)\end{array}$ \\
\hline Carboxin $37.5 \%$ + Thiram $37.5 \%$ & $\begin{array}{c}\text { Vitavax } \\
\text { power }\end{array}$ & $\begin{array}{c}100.00 \\
(90.05)^{*}\end{array}$ & $\begin{array}{l}100.00 \\
(90.05)\end{array}$ & $\begin{array}{l}100.00 \\
(90.05)\end{array}$ & $\begin{array}{l}\mathbf{1 0 0 . 0 0} \\
(90.05)\end{array}$ \\
\hline \multicolumn{2}{|l|}{ Mean } & $\begin{array}{c}87.25 \\
(75.58)\end{array}$ & $\begin{array}{c}92.38 \\
(\mathbf{8 0 . 8 4})\end{array}$ & $\begin{array}{c}94.14 \\
(83.98)\end{array}$ & $\begin{array}{c}91.26 \\
(80.13)\end{array}$ \\
\hline & & \multicolumn{2}{|c|}{ S.Em \pm} & \multicolumn{2}{|c|}{ CD at $1 \%$} \\
\hline $\begin{array}{c}\text { Fungicides }(\mathbf{F}) \\
\text { Concentrations } @ \\
\text { FXC }\end{array}$ & & & & & \\
\hline
\end{tabular}

*Arcsine transformed values

Table.2 In vitro evaluation of contact fungicides against Rhizoctonia bataticola

\begin{tabular}{|c|c|c|c|c|}
\hline \multirow{3}{*}{ Fungicides } & \multicolumn{3}{|c|}{ Inhibition of mycelial growth (\%) } & \multirow{3}{*}{ Mean } \\
\hline & \multicolumn{3}{|c|}{ Concentrations $(\%)$} & \\
\hline & 0.1 & 0.2 & 0.3 & \\
\hline Captan & $\begin{array}{c}66.11 \\
(54.43)\end{array}$ & $\begin{array}{l}74.31 \\
(59.57)\end{array}$ & $\begin{array}{c}82.64 \\
(65.41)\end{array}$ & $\begin{array}{c}\mathbf{7 4 . 3 5} \\
(59.81)\end{array}$ \\
\hline & 80.56 & 100.00 & 100.00 & 93.52 \\
\hline Cniorothalonil & $(64.00)$ & $(90.05)$ & $(90.05)$ & $(81.36)$ \\
\hline Conner oxvchloride & 0.00 & 0.00 & 0.00 & 0.00 \\
\hline copper oxycnioride & $(0.00)^{*}$ & $(0.00)$ & $(0.00)$ & $(0.00)$ \\
\hline & 70.14 & 100.00 & 100.00 & 90.04 \\
\hline VIancozed & $(56.88)$ & $(90.05)$ & $(90.05)$ & $(79.00)$ \\
\hline \multirow[t]{2}{*}{ Mean } & $\begin{array}{c}54.20 \\
(43.83)\end{array}$ & $\begin{array}{c}68.58 \\
(59.92)\end{array}$ & $\begin{array}{l}70.66 \\
(61.38)\end{array}$ & $\begin{array}{c}64.48 \\
(55.04)\end{array}$ \\
\hline & \multicolumn{2}{|c|}{ S.Em \pm} & \multicolumn{2}{|c|}{ CD at $1 \%$} \\
\hline Fungicides (F) & \multicolumn{2}{|c|}{0.35} & \multicolumn{2}{|c|}{2.33} \\
\hline Concentrations $(\underset{)}{ }$ & \multicolumn{2}{|c|}{0.30} & \multicolumn{2}{|c|}{2.16} \\
\hline FXC & \multicolumn{2}{|c|}{0.61} & \multicolumn{2}{|c|}{3.07} \\
\hline
\end{tabular}

*Arcsine transformed values 
Plate.1 In vitro evaluation of fungicides against Rhizoctonia bataticola
1) Saaf
2) Sprint
3) Vitavax power
4) Merger
5) Avtar
6) Taquat
C) Control

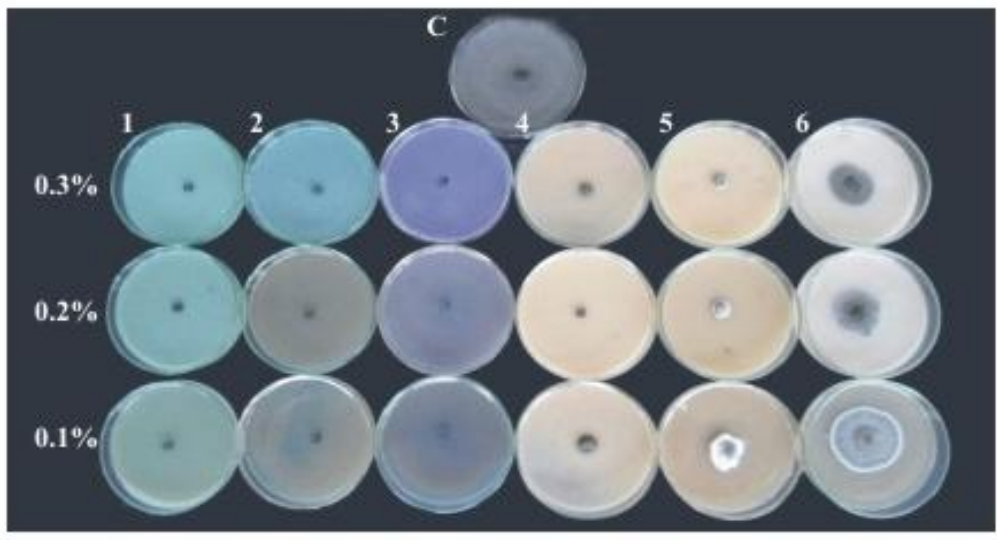

a) Combi products

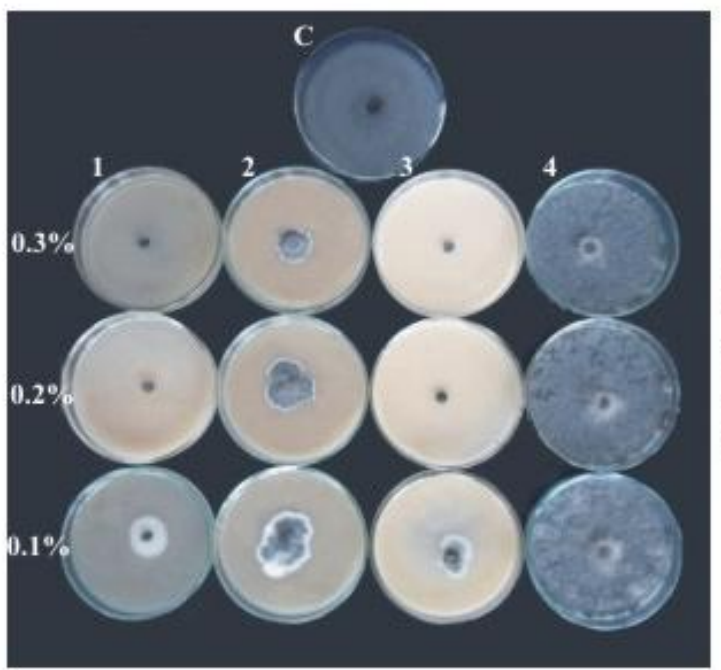

1) Chlorothalonil

2) Captan

3) Mancozeb

4) Copper oxychloride

C) Control

b) Contact fungicides

1) Carbendazim

2) Difenconazole

3) Tebuconazole

4) Hexaconazole

C) Control

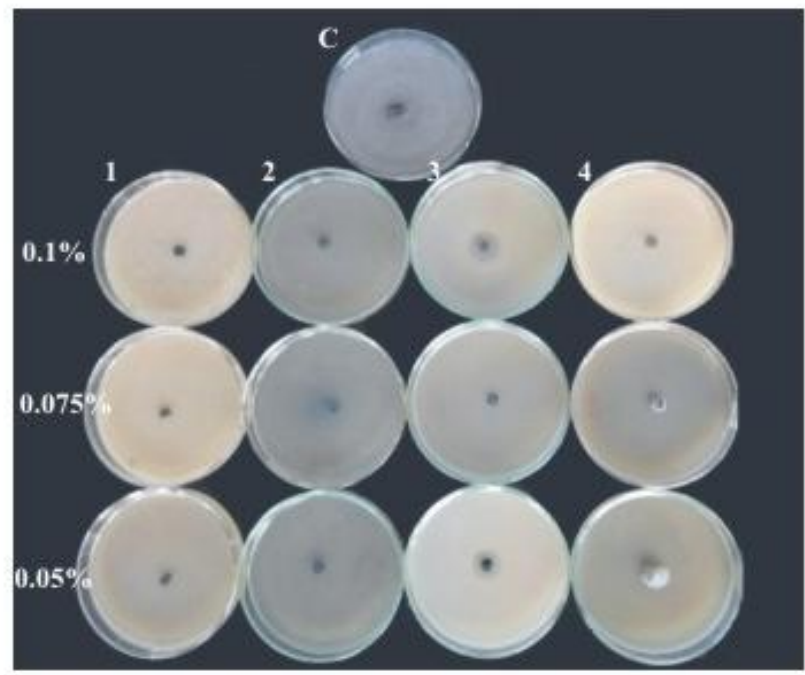

c) Systemic fungicides 
Table.3 In vitro evaluation of systemic fungicides against Rhizoctonia bataticola

\begin{tabular}{|c|c|c|c|c|}
\hline \multirow{3}{*}{ Fungicides } & \multicolumn{3}{|c|}{ Inhibition of mycelial growth (\%) } & \multirow{3}{*}{ Mean } \\
\hline & \multicolumn{3}{|c|}{ Concentrations $(\%)$} & \\
\hline & 0.1 & 0.2 & 0.3 & \\
\hline Carbendazim & $\begin{array}{c}100.00 \\
(90.05) *\end{array}$ & $\begin{array}{l}100.00 \\
(90.05)\end{array}$ & $\begin{array}{l}100.00 \\
(90.05)\end{array}$ & $\begin{array}{l}100.00 \\
(90.05)\end{array}$ \\
\hline & 100.00 & 100.00 & 100.00 & 100.00 \\
\hline Difenconazole & $(90.05)$ & $(90.05)$ & $(90.05)$ & $(90.05)$ \\
\hline & 95.00 & 100.00 & 100.00 & 98.33 \\
\hline Hexaconazole & $(77.15)$ & $(90.05)$ & $(90.05)$ & $(85.75)$ \\
\hline Tehuconazole & 100.00 & 100.00 & 100.00 & 100.00 \\
\hline rebuconazole & $(90.05)$ & $(90.05)$ & $(90.05)$ & $(90.05)$ \\
\hline \multirow[t]{2}{*}{ MEAN } & $\begin{array}{c}98.75 \\
(86.82)\end{array}$ & $\begin{array}{l}100.00 \\
(90.05)\end{array}$ & $\begin{array}{l}100.00 \\
(90.05)\end{array}$ & $\begin{array}{l}99.58 \\
(88.97)\end{array}$ \\
\hline & \multicolumn{2}{|c|}{ S.Em \pm} & \multicolumn{2}{|c|}{ CD at $1 \%$} \\
\hline Fungicides $(\mathbf{F})$ & \multicolumn{2}{|c|}{0.09} & \multicolumn{2}{|c|}{1.20} \\
\hline Concentrations $\subset$ & \multicolumn{2}{|c|}{0.08} & \multicolumn{2}{|c|}{1.11} \\
\hline FXC & \multicolumn{2}{|c|}{0.16} & \multicolumn{2}{|c|}{1.57} \\
\hline
\end{tabular}

*Arcsine transformed values

Wherein non-systemic protectant fungicides affect too many functions in fungal physiology and to develop resistance the fungus will have to make too many gene changes. Hence the combination of both systemic and non-systemic fungicides provides better management of plant fungal disease for long duration.

\section{In vitro evaluation of contact fungicides}

Among the contact fungicides tested, chlorothalonil gave the best results by maximum inhibition of mycelial growth $(93.52 \%)$ which was significantly superior to all other fungicides, followed by mancozeb $(90.04 \%)$, there was no inhibition of mycelial growth in the copper oxychloride at all the concentrations. In different concentrations chlorothalonil and mancozeb at $0.2 \%$ was effective in inhibiting cent per cent inhibition (Table 2 and Plate 1).

\section{In vitro evaluation of systemic fungicides}

Among the four systemic fungicides evaluated against $R$. bataticola, carbendazim, difenconazole and tebuconazole were best with cent per cent inhibition of mycelial growth at all concentrations $(0.05,0.075$ and $0.1 \%)$ and significantly superior to hexaconazole with $98.33 \%$ inhibition and it also recorded cent per cent inhibition at $0.075 \%$ and $0.1 \%$ (Table 3 and Plate1). Results are in agreement with Sangeetha and Jahagirdar (2013).

The general mode of action of systemic fungicides is associated with interference with the electron transport chain influencing the energy budget of the cell, reduction in the biosynthesis of new cell material required for growth and development of the organism and disruption of cell structure and permeability of cell membrane.

In conclusion, carbendazim $25 \%+$ mancozeb 50\% (Sprint), carboxin 37.5\% + thiram 37.5\% (Vitavax power $75 \% \mathrm{WP}$ ) and carbendazim $12 \%$ + mancozeb $63 \%$ (Saaf), chlorothalonil and mancozeb at $0.2 \%$, difenconazole and tebuconazole were the best fungicides against $R$. bataticola with cent per cent inhibition of mycelial growth. 


\section{References}

Ammajamma, R. and Yashoda Hegde. 2009. Efficacy of fungicides against Rhizoctonia bataticola causing wilt of Coleus forskohlii. Int. J. Pl Prot., 2(1): 31-32.

Hegde, Y.R., Ammajamma, R. and Venugopal, C.K. 2014. Integrated management of wilt complex of coleus forskholii. The Bioscan, 9(1): 425-427.

Nene, Y.L. and Thapliyal, P.N. 1973. Fungicide in plant diseases control (Third Edition). Oxford and IBH publishing Co. Pvt. Ltd., New Delhi, p. 325.
Ravichandran, S., Hegde, Y.R., Math, G. and Uppinal, N.F. 2014. Survey for chickpea wilt complex in northern Karnataka. Nation. Symp. Plant diseases: New perspectives and innovative management strategies.11-12, December, 2014, UAS, Dharwad (India), p. 29.

Sangeetha, T.V. and Jahagirdar, S. 2013. Screening of new molecules of fungicides against Sclerotium rolfsii, Rhizoctonia bataicola and Fusarium sp. causing root rot/ wilt complex of soybean.

Vincent, J.M. 1947. Distortion of fungal hyphae in presence of certain inhibitors, Nature, 159: 239-241.

\section{How to cite this article:}

Ravichandran, S. and Yashoda R. Hegde. 2017. Management of Dry Root Rot of Chickpea Caused by Rhizoctonia bataticola through Fungicides. Int.J.Curr.Microbiol.App.Sci. 6(7): 1594-1600. doi: https://doi.org/10.20546/ijcmas.2017.607.192 